\title{
Fenomena Sosiologis Petani Pedesaan yang Terpinggirkan di Indonesia
}

\section{Mohammad Wahed, Ririt Iriani Sri Setiawati, Kiki Asmara}

Universitas Pembangunan Nasional Veteran Jawa Timur

Email: Muhammadwahed124@gmai.com,riritfebupn@gmail.com, kikyasmara25@gmail.com

\begin{tabular}{l}
\hline Article Info \\
\hline Article history: \\
Published: Dec 25,2020 \\
Page: $24-37$ \\
\hline \\
Keyword: \\
Development Paradigm, \\
Farmer Entity,Empowerment, \\
Rural Farmers, Populist \\
Economy Concept.
\end{tabular}

\section{Pendahuluan}

Indonesia memiliki identitas sebagai negara agraris yang memiliki kekayaan alam berlimpah baik berupa rempah-rempah maupun hasil pangan seperti beras, umbiumbian, dan jagung (Normansyah, Rochaeni, dan Humaerah 2014). Berdasarkan kondisi alam tersebut, sebagian besar penduduknya bermatapencaharian sebagai petani (Ilham et all, 2007). Dataran
Penelitian ini merupakan studi pustaka mengenai perubahan fenomina sosial masyarakat petani pedesaan di Indonesia, pola-pola perilaku dan sistem interaksi sosial, termasuk di dalamnya perubahan norma, nilai, dan fenomena kultural. Keterbatasan petani merupakan salah satu sebab yang mendasari terjadinya kemiskinan. Kata Kunci: Paradigma Pembangunan, Entitas Petani, Pemberdayaan, Petani Pedesaan, Konsep Ekonomi Kerakyatan.

This research is a literature study regarding changes in the social phenomena of rural farmer communities in Indonesia, behavior patterns and social interaction systems, including changes in cultural norms, values and phenomena. The limited number of farmers is one of the reasons that underlie poverty.

Keywords : Development Paradigm, Farmer Entity, Empowerment, Rural Farmers, Populist Economy Concept.

Copyright @ 2020 OECONOMICUS Journal of Economics

\section{Editorial Office:}

Prodi Ilmu Ekonomi Fakultas Ekonomi dan Bisnis Islam, UIN Sunan Ampel Surabaya

Jl. Ahmad Yani 117 Surabaya, Jawa Timur 60237, Indonesia.

Email: oje@uinsby.ac.id

tanah yang subur di wilayah nusantara ini menjadikan potensi untuk membuka kesempatan bagi warganya dalam bercocok tanam, sehingga bidang pertanian mampu memberikan kontribusi nyata terhadap usaha masyarakat tani khususnya yang hidup di pedesaan (Wiradi, 2004). Semakin jelas bahwa sektor pertanian mampu memberikan kontribusi secara langsung terhadap pertumbuhan ekonomi dan 
peningkatan kesejahteraan rumah tangga tani.

Peran petani tidak dapat dilepaskan dalam kehidupan masyarakat Indonesia, karena petani memiliki peran sebagai pemasok kebutuhan pangan utama Nasional berupa beras, jagung, kedelai, dll. Pentingnya peran petani bagi bangsa Indonesia belum mampu menjelaskan kesejahteran hidup petani, adanya masalah kemiskinan yang masih terjadi pada keluarga petani (Wiradi, 2004). kondisi kemiskinan dapat dilukiskan sebagai kurangnya pendapatan untuk memenuhi kebutuhan hidup pokok seperti pangan, sandang, perumahan, dan lain-lain (Rohmiati amini, 2018).

Tingkat kemiskinan merupakan indikator yang dapat menggambarkan taraf kesejahteraan hidup masyarakat secara umum (BPS, 2018). Menurut (Mosher dalam Sinaga \& Sumardjo, 2007), hal yang paling penting dari kesejahteraan adalah pendapatan, karena dari beberapa aspek kesejahteraan rumah tangga tergantung pada tingkat pendapatan. Dengan kata lain, apabila terjadi peningkatan pendapatan dengan tidak merubah pola konsumsi maka rumah tangga tersebut sejahtera (Nuraini 2018). Sebaliknya, apabila peningkatan pendapatan rumah tangga dapat merubah pola konsumsi maka rumah tangga tersebut tidak sejahtera. Sulitnya upaya untuk meningkatkan pendapatan petani dikarenakan masayarakat tani masih dihadapkan dengan berbagai masalah pelik dibidang pertanian, seperti terjadinya perubahan struktur kepemilikan lahan ( Niel Robert Van dalam Kurniawan, 2014).
Lebh lanjut, terjadi penyusutan lahan pertanian produktif akibat pesatnya perkembangan pembangunan di berbagai sektor ekonomi yang menuntut ketersedian lahan dan sarana prasarana yang memadai (saptana dalam Budhijana, 2014). Kondisi ini terutama terjadi di Jawa, dimana(Ariani, Bahri, \& Arif 2016), mengestimasikan ratarata 23.100 hektar per tahun lahan di Jawa terkonversi ke penggunaan diluar pertanian. Gejala marjinalisasi petani dan kemunduran perekonomian pedesaan menjadi sulit dielakkan.

Elizabeth (2016) menjelaskan bahwa kebijakan harga dengan tujuan mensejahterakan petani mejadi tidak efektif, kebijakan tersebut justru hanya dinikmati oleh petani yang memiliki lahan luas. Keadaan petani kecil yang jumlahnya jauh lebih banyak hanya menerima upah buruh atau bagi hasil yang relative rendah sehingga tidak memiliki pengaruh yang signifikan terhadap peningkatan kesejahteraan masyarakat petani, keadaan tersebut tambah di perparah dengan kurangnya dukungan data dan informasi yang tidak akurat mengenai profil petani dan kelembagaan pendukungnya.

Perhatian terhadap masalah pertanian khususnya yang menyangkut pendapatan petani, struktur kepemilikan lahan, akses terhadap pasar output pertanian, dan bermuara pada kesejahteraan petani sudah cukup lama mendapatkan perhatian dari para ahli. Perhatian tersebut sangat tampak ketika (Sadono, 2008) menyimpulkan dalam penelitiannya bahwa diperlukan perubahan paradigma dari paradigma lama yang lebih menekankan pada alih teknologi ke paradigma baru yang mengutamakan pada 
sumberdaya manusianya, yang dikenal dengan pendekatan Farmer First, atau "mengubah petani" dan bukan "mengubah cara bertani", yang memungkinkan terjadi pemberdayaan pada diri petani.

Strategi pemberdayaan memiliki keterkaitan kuat dengan kondisi sosio-teknis petani (Suharto, 2014). Strategi pemberdayaan merupakan suatu pendulum antara pradigma evolusi dan pradigma revolusi, namun tidak berarti setiap paradigm akan muncul secara total (Suradisastra, 2008). Kedua paradigma tersebut merupak suatu gradasi dengan proporsi yang sesuai dengan kebutuhan masyarakat petani. Pengembangan model pemberdayaan akan selalu berada diantara kedua paradigma tersebut dengan proporsi yang sejalan dengan tuntutan kebutuhan dari masyarakat petani.

Pentingnya pemberdayaan lewat penelitian (Tanziha, 2011), (Rohmiati amini, 2018), (Miftah \& Syarbaini 2014), (Ariani, Bahri, \& Arif 2016), (Pendapatan et al. 2017), (Ferianti 2018) upaya pemberdayaan pertanian yang terwujud dari partisipatif aktif petani dalam setiap pelaksanaan program pertanian melalui kaidah-kaidah dan penerapan teknologi pada program tersebut. Melalui integrasi antara teknologi dan program pertanian diharapkan dapat meningkatkan manfaat dari pertanian yang berbasis ekologi. Nilai tukar petani semakin bertambah dan diimbangi dengan penurunan biaya produksi dalam penggunaan bahan kimiawi sehingga bida berdampak pada peningkatan kesejahteraan petani. Sinergitas antara pihak pemberdaya dengan pihak yang diberdayakan akan saling mendukung satu sama lain untuk tercapainya tujuan pemberdayaan itu sendiri.

Dengan demikian, tulisan ini bertujuan memahami fenomena petani melalui pemberdayaannya sebagai bentuk keberpihakan pada masyarakat petani di pedesaan yang terpinggirkan. Pertanyaan yang penting untuk dijawab: Benarkah petani di pedesaan sungguh dapat berpartisipasi di dalamnya? Bagaimana perubahan struktur social petani di pedesaan? bagaimana eksistensi petani di pedesaan dalam proses pembangunan yang kurang berpihak? Karena itu penelitian ini hendak menjawab pertanyaan: Bagaimana Posisi dan Peran Petani Pedesaan di Indonesia?

\section{Kajian Pustaka}

\section{A. Petani}

Istilah "petani" dari banyak kalangan akademis sosial akan memberikan pengertian dan definisi yang beragam. Menurut (Mosher dalam Rohmiati amini 2018) memberi batasan bahwa petani adalah manusia yang bekerja memelihara tanaman dan atau hewan untuk diambil manfaatnya guna menghasilkan pendapatan. Ciri-ciri masyarakat petani sebagai berikut: 1) satuan keluarga (rumah tangga) petani adalah satuan dasar dalam masyarakat desa yang berdimensi ganda, 2) petani hidup dari usahatani, dengan mengolah tanah (lahan), 3) pola kebudayaan petani berciri tradisional dan khas, dan 4) petani menduduki posisi rendah dalam masyarakat, mereka adalah 'orang kecil' terhadap masyarakat di atasdesa (Budhijana, 2014).

Petani sebagai sosok individu memiliki karakteristik tersendiri secara individu yang 
dapat dilihat dari perilaku yang nampak dalam menjalankan kegiatan usaha tani. Undang Undang Nomor 19 Tahun 2013 tentang Perlindungan dan Pemberdayaan Petani dalam Pasal 1 ayat (3) menyatakan bahwa petani adalah warga negara Indonesia perseorangan dan atau beserta keluarganya yang melakukan usaha tani di bidang tanaman pangan, holtikultura, perkebunan dan atau peternakan.

\section{B. Perubahan Sosial}

Setiap masyarakat manusia selama hidup pasti mengalami perubahanperubahan. Perubahan dapat berupa yang tidak menarik atau dalam arti kurang mencolok. Menurut Max Weber, bahwa tindakan sosial atau perubahan sosial tidak bisa dipisahkan dari proses berpikir rasional dan tujuan yang akan dicapai oleh pelaku.

Lebih lanjut (Melati, 2013) membagi kedalam tiga jenis perubahan social yaitu: 1) social evolution (Evolusi Sosial); 2) sosial mobility (Mobilitas Sosial); dan 3) sosial revolution (Revolusi Sosial). Ketiga bentuk perubahan sosial diatas dapat dijabarkan satu persatu misalnya evolusi sosial, ini merupakan suatu bentuk perubahan social dimana perubahan yang sifatnya lambat, karena perubahan yang terjadi dengan sendirinya dan tidak didahului dengan adanya rencana. Kemudian perubahan dalam bentuk mobilitas sosial, dimana suatu perubahan yang terjadi karena adanya keinginan manusia akan hidup yang lebih baik dan layak. Bentuk perubahan ini bersifat adanya gerakan sosial karena munculnya konsep-konsep dan ide-ide baru.

\section{Sistem Kekerabatan}

Kekerabatan adalah inti utama dari studi dalam disiplin ilmu antropologi, demikian yang pernah dikatakan oleh Fox (dalam Kuper, 2000) yang menyatakan bahwa "Kekerabatan adalah milik antropologi...". P Malinowski (dalam Kuper, 2000) mengemukakan bahwa keluarga adalah institusi domestik, bergantung pada afeksi dan bertujuan membesarkan anak. Koorporasi keturunan adalah institusi public dan politik yang mempunyai suatu peran dalam urusan komunitas dan pengaturan hak-hak kepemilikan (Property Rights). Lebih lanjut (Meiyenti, 2014) berpandangan bahwa system kekerabatan yang lebih luas dibangun di atas pondasi keluarga. Fungsi keturunan adalah untuk meregulasi transmisi kepemilikan dan hak masyarakat dari generasi ke generasi.

Teori umum mengenai system kekerabatan berdasarkan konsep tukar menukar wanita itu dimulai dengan membedakan adanya dua golongan system kekerabatan dengan dua kategori struktur, yaitu: 1) structures elementaires, atau struktur-struktur elementer dengan aturanaturan yang tegas, yang mengakibatkan bahwa para warga kelompok kekerabatan itu mengetahui dengan gadis atau wanita mana, dan dari kelompok mana, mereka dapat menikah; dan 2) struktur-struktur kompleks, dengan aturan-aturan yang hanya membatasi kelompok kekerabatan sendiri, tetapi tidak mempunyai aturan-aturan yang tegas yang menentukan dengan gadis atau wanita mana di luar kelompok sendiri itu seseorang boleh menikah (Meiyani, 2010).

\section{Restrukturisasi Pertanian}

Dalam rangka menempatkan sektor pertanian menjadi andalan pengembangan perekonomian rakyat dan pedesaan, maka perlu ditempuh langkah-langkah untuk 
merubah struktur pertanian yang ada. Karakteristik usahatani rakyat dicirikan oleh sifat usaha kecil, pengelolaan independen, dan menyebar dalam kawasan yang luas (dispersal). Konsekwensinya adalah volume produksi terbatas, kwalitas produk dan waktu panen bervariasi, dan biaya pengumpulan produk relatif besar sehingga kurang kondusif sebagai basis pengembangan agroindustri dan sistem pemasaran yang efisien.

Berdasarkan pada permasalahan tersebut maka strategi yang tepat untuk mendorong perkembangan pertanian di pedesaan adalah konsolidasi vertikal. Usahatani skala kecil dikonsolidasikan oleh suatu usaha industri pertanian atau pemasaran dalam suatu organisasi usaha kemitraan sehingga tercipta satu unit agribisnis industrial. Pola kemitraan haruslah didasarkan pada kesadaran semua pihak bahwa mereka saling membutuhkan dan hanya dapat tumbuh bersama sehingga harus bermitra dengan prinsip transparan, adil, patuh aturan kesepakatan, dan terpercaya.

Kepemilikan Lahan

Menurut (Korten \& Sjahrir dalam Suyanto 2001) konsepsi dari pemikiran neoklasik yang di adopsi dalam paradigma pembangunan pertanian tampaknya kurang berhasil untuk mencapai pertumbuhan yang adil dan merata, justru dengan penerapan paradigma tersebut menciptakan ketergantungan ditingkat nasional dan lokal. Peran dari pemerintah menjadi terlalu jauh dalam proses hegemoni globalisasi dan pemudahan pelaksanaan kontrol global yang seringkali menyingkirkan norma dan nilai sosial lokal, sehingga dampaknya adalah strategi pemerataan pembangunan melalui Trickle Down Effect sulit diimplementasikan. Hal ini karena di satu sisi sumberdaya terkonsentrasi pada sebagian kecil masyarakat berkualitas dan berkuantitas ekonomi yang relatif sudah mapan.

Di sisi lain, menurut (Hayami \& Kikuchi dalam Budhijana, 2014) proses pembangunan yang sarat dengan nuansa Capital menciptakan polarisasi yang begitu cepat dimana sebagian besar terpaksa melepaskan penguasaan sumberdaya lahan menjadi kelompok petani gurem bahkan Landless yang masuk dalam klaster buruh tani atau kelompok masyarakat miskin. Kondisi tersebut diperburuk oleh krisis ekonomi yang melanda Indonesia yang berdampak pada bertambahnya jumlah penduduk miskin. Berdasar data BPS (1998), pemerintah berhasil menurunkan jumlah penduduk miskin dari 54,2 juta (1976) menjadi 22,5 juta, namun kembali meningkat sekitar 23,8 persen menjadi 49,5 juta pada awal tahun 1999 yang ditenggarai sebagai akibat krisis tersebut.

\section{F. Pemberdayaan Petani}

Menurut Shardlow (Ferianti, 2018) melihat bahwa pemberdayaan, pada intinya membahas bagimana individu, kelompok, ataupun komunitas berusaha mengontrol kehidupan mereka sendiri dan mengusahakan untuk membentuk masa depan sesuai dengan keinginan mereka. Pemahaman pendekatan aras makro ini di dalam upaya pemberdayaan untuk meningkatkan kesejahteraan petani di pedasaan yang dilakukan melalui suatu strategi, yaitu strategi penguatan potensipotensi pendapatan. Strategi ketahanan 
pangan sendiri didalamnya terbagi kedalam tiga komponen utama, yaitu ketersediaan pangan, distribusi pangan dan konsumsi pangan.

Pemberdayaan yang dikemukakan oleh (Tanziha, 2011) memiliki tiga dimensi yang merujuk pada: 1) Sebuah proses pembangunan bermula dari pertumbuhan individual yang kemudian berkembang menjadi sebuah perubahan sosial yang lebih besar; 2) Sebuah keadaan psikologis yang ditandai oleh rasa percaya diri, berguna dan mampu mengendalikan diri dan orang lain; 3) Pembebasan yang dihasilkan oleh gerakan sosial, yang dimulai dari pendidikan dan politisasi orang-orang lemah dan kemudian melibatkan upaya-upaya kolektif dari orang-orang lemah tersebut untuk memperoleh kekuasaan dan mengubah struktur-struktur yang masih menekan.

\section{Metode Penelitian}

Metode yang digunakan dalam pemecahan permasalahan termasuk metode analisis. Metode-metode yang digunakan dalam penyelesaian penelitian dituliskan di bagian ini.

\section{Hasil dan Pembahasan}

\section{A. Dinamika dan Entitas Sosial Petani Pedesaan}

Petani di Indonesia memiliki cirikhas dan keunikan tersendiri, petani Jawa sejak awal terbentuk dari moral ekonominya yang subsisten. Menurut (James C. Scott dalam Budhijana 2014) menjelaskan bahwa petani menganut prinsip utamakan selamat. Para petani lebih senang meminimalisir kemungkinan terjadinya suatu bencana (gagal panen) daripada meningkatkan penghasilannya. Dalam memilih bibit dan cara bertanam para petani lebih menghindari risiko daripada melakukan spekulasi untuk meningkatkan penghasilannya. Untuk itulah petani lebih senang menanam tanaman pangan atau dengan kata lain petani nasional menganut sistem pertanian subsisten (Kurniawan, 2014).

Namun demikian, dalam perkembangan sistem pertanian sedikit demisedikit mengalami perubahan yang diakibatkan dari berbagai regulasi (program) pemerintah seperti program sistem tanam paksa yang berorentasi pada komoditas ekspor. sistem tanam paksa telah mengubah pola yang sejak dulu diyakini oleh para petani. Mereka dipaksa menanam tanaman ekspor untuk kepentingan ekonomi Belanda. Hal ini otomatis mengurangi produksi tanaman pangan mereka. Peralihan dari produksi subsistensi ke produksi komersil hampir selalu memperbesar risiko. Selain itu produksi komersil dalam sistem tanam paksa tidak menjamin persediaan pangan bagi keluarga. Akibat dari sistem tanam paksa maka memaksa petani untuk mengubah pola pikirnya.

Perubahan dalam sistem kerja juga telah mengenalkan sistem ekonomi uang ke dalam lingkungan kehidupan pedesaan agraris (Elizabeth, 2016). Kehidupan perekonomian yang semula masih tradisional dan subsisten secara berangsur-angsur berkenalan dengan ekonomi uang melalui komersialisasi produksi pertanian dan pasaran kerja. Sistem tanam paksa telah menjadi pintu masuk peredaran uang ke daerah pedesaan. Sistem ekonomi uang ini membuat para petani mulai tergantung pada dunia luar. Produksi pertanian dirasakan sebagai komoditi untuk 
ekspor dan pasar dunia. Sistem ini mulai menggoyang sistem ekonomi subsisten sebagai ekonomi tradisional yang bersifat tertutup dan memenuhi kebutuhan rumah tangga sendiri bagi petani.

Lebih lanjut, terjadinya polarisasi yang sangat cepat dialami oleh masyarakat petani disebut White sebagai proses eksploitasi (penghisapan) dari golongan kapitalis terhadap masyarakat di bawahnya. Sedangkan petani dari segi ekonomi, pandangan terhadap petani dinisbatkan pada kemampuan mereka dalam memperoleh pendapatan berdasarkan sekian liter beras. Dalam struktur sosial kehidupan bermasyarakat pada umumnya para petani merupakan kelompok masyarakat dengan klasifikasi paling bawah, seperti juga halnya kehidupan para nelayan. Selain itu juga pertumbuhan populasi (angkatan kerja, migrasi) dan perkembangan teknologi menjadi pemacu dalam keadaan ini yang pada akhirnya menempatkan kaum petani berada di posisi yang semakin lemah.

Penetrasi ekonomi kapitalis di kehidupan masyarakat tani di pedesaan dalam bentuk penerapan teknologi modern dan sistem pasar yang mengutamakan efisien serta perubahan nilai ekonomi lahan hanya menyebabkan tingginya konversi tanah dari pertanian ke non-pertanian. Kondisi ini berdampak pada hilangnya kesempatan bertani bagi sebagian besar buruh tani dan sekaligus menyebabkan semakin longgarnya ikatan-ikatan sosial yang terjalin dalam kehidupan masyarakat pedesaan. Dampak sosiologis lain dari ekonomi kapitalis tersebut tidak hanya dalam kehidupan masayarakat petani, namu lebih luas sudah mempengaruhi tujuan produksi petani, strategi, nilai dan norma, serta orientasi hidup, bahkan kemungkinan untuk terjadinya proses Depeasantisasi akibat semakin membudaynya iklim konsumtif yang sudah merambah hingga ke pedesaan.

\section{B. Dimensi dan Perubahan Struktur Sosial Petani}

Perubahan Sosial dan Budaya mengkaji mengenai perubahan pada masyarakat yang di dalamnya bermuatan budaya yang dimilikinya sebagai akibat dari berlakunya globalisasi sistem ekonomi (Melati, 2013). Kehidupan masyarakat petani di pedesaan identik dengan ciri khusus dan keunikan pada prilaku soialnya. Dalam konteks prilaku mata pencahariannya masyarakat pedesaan biasanya hanya bermata pencaharian sebagai petani di sawah-sawah setempat, berperilaku secara sopan santun, berpakaian secara sederhana, berpikiran sempit atau tidak berorientasi untuk maju, tidak mengutamakan peningkatan perekonomian dalam hidupnya, sulit dipengaruhi budaya dari luar, masyarakatnya bersifat homogen, tempat tinggal dan harta benda yang masih sederhana.

Tetapi sejak munculnya tekanan globalisasi sistem ekonomi dengan kecendrungan kapitalis lambat laun masyarakatnya serta budaya masyarakat pedesaan sudah mengalami perubahan. Perubahan sosial yang dikemukakan (Soekanto dalam Sidiq, 2014), merupakan mobilitas sosial vertikal melalui perpindahan individu atau objek sosial ke kedudukan sosial lainnya yang tidak sederajat. Menurut (Dickson dalam Elizabeth, 2016) perubahan juga terlihat 
pada gaya hidup yang ditampilkan antara kelas sosial satu dengan kelas sosial lain, bahkan ada kecenderungan masing-masing kelas mencoba mengembangkan gaya hidup yang eksklusif untuk membedakan dirinya dengan kelas yang lain.

Pada masa kini petani merupakan masyarakat yang memiliki kemampuan mengadopsi perkembangan teknologi pertanian. Sementara itu, (Melati, 2013) meneliti petani secara antropologis atau historis mulai dari manusia primitif hingga menjadi petani modern. Dari berbagai konsep dan pemikiran perbandingan petani dari primitif hingga modern dapat di ilustraikan pada tabel 1 .

Tabel 1. Perbandingan Masyarakat

Rpimitif, Petani, dan Petani Modern

\begin{tabular}{lll}
\hline Primitif (Tribe) & Petani (Peasant) & Petani Modern (Farmer) \\
\hline Bertani berpindah & Bertani tetap & Rumah kaca \\
Kebuttuhan primer dan kerabat & Subsisten & Keuntungan maksimum \\
Ada ikatan dengan tetangga & Ada ikatan nilai-nilai & Hubungan longgar dalam \\
Surplus diserahkan ke & Surplus diserahkan ke & simbol \\
golongan & penguasa & Surplus sebagai keuntungan \\
Intensitas hubungan.dengan & Intensitas hub.dengan luar & Mobilitas tinggi \\
luar & tinggi & Spesialisasi/profesional \\
rendah & Semi spesialisasi atau & Cenderung sewa \\
Belum ada spesialisasi & campuran & \\
Belum ada sewa tanah & Sudah ada sewa tanah. & \\
\hline
\end{tabular}

Di era globalisasi seperti sekarang ini perbandingan masyarakat petani yang masuk kategori primitif atau tradisional dengan masyarakat petani yang masuk kategori semi komersial atau komersial (Modern) sudah tidak bisa ditentukan oleh jenis pekerjaannya saja akan tetapi lebih ditentukan pada kualitas sumberdaya manusianya. Sedangkan dari perspektif kualitas ini bisah dilihat dari berbagai indikator, diantaranya: 1) sejauh mana visi dan misi kehidupannya di masa kini dan masa mendatang; dan 2) investasi di bidang pangan, gizi, kesehatan, dan investasi dibidang pendidikan.

Lebih lanjut, Van Vollenhoven (Gambar 1) menggambarkan masyarakat petani sebagai masyarakat desa yang dilatarbelakangi kesatuan agroekosistem (alam/geografi) dan kebudayaan. Kesatuan lingkungan geografisnya terutama yang berkaitan dengan penguasaan dan pengusahaan sumberdaya lahan. Sedangkan kesatuan kebudayaan meliputi berbagai aturan sosial yang berlaku dalam kehidupan masyarakat petani itu sendiri. Berbagai aturan tersebut antara lain meliputi aturan adat, penduduk asli, tanah, lahan garapan, hubungan kekeluargaan, dan kehidupan ekonomi masyarakat desanya.

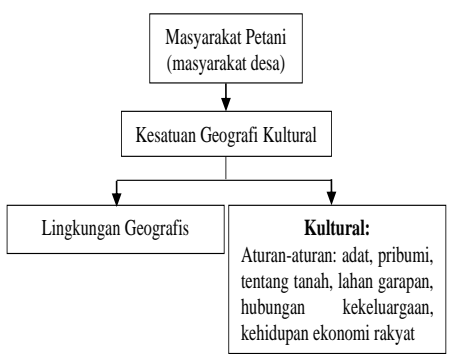

Gambar 1. Bagan Masyarakat Petani di Desa (Van Vollenhoven)

Ciri khusus yang sekaligus menjadi pembeda masyarakat petani dengan masyarakat lain adalah masyarakat sebagai entitas yang memiliki struktur dan kultur yang khas. Beberapa ciri khusus petani yang dianggap sama dimana saja, yaitu (Budhijana, 2014): 1) keluarga adalah sebagai kelompok sosial; 1) keterikatan mistik terhadap pertanian; dan 3) tekanan pada prokreasi. Lebih lanjut, (Ismail, Suprapti, \& Sri, 2008) menegaskan bahwa ciri petani tersebut bersifat kedesaan tetapi aktivitas kehidupan masyarakat petani berhubungan dengan pemenuhan komoditi 
kebutuhan bahan pangan terhadap pasar di kota yang sekaligus menjadikannya sebagai bagian masyarakat dan budaya. Sedangkan (Wiradi, 2004) melihat petani melalui beberapa ciri, yaitu: mereka yang memandang aktifitas pertanian sebagai sumber mata pencaharian dan cara kehidupan, bukan sebagai usaha untuk mencari keuntungan. Dapat disimpulkan bahwa petani yang mengerjakan pertanian untuk penanaman modal kembali dan usaha (tanah sebagai modal dan komoditi) merupakan pengusaha pertanian dan bukan peasant (Elizabeth, 2016).

Selaras dengan kkonsep diatas, menerangkan bahwa masyarakat petani merupakan masyarakat yang memiliki kesamaan dengan tipe masyarakat lain baik di dunia Barat maupun Timur (Sadono, 2008). Kesamaan yang dimaksuda dalam pengertian ini adalah: 1) adanya ikatan pribadi dengan tanah; 2) keterikatan kepada desa atau komunitas lokal; 3) pentingnya keluarga secara sentral; 4) perkawinan sebagai persiapan kecukupan ekonomi menuju makmur; dan 5) adanya ketegangan antara keterikatan kepada tanah dan dunia lokal dengan keharusan menghasilkan tanaman penghasil uang begitu seterusnya. Merujuk pada pernyataan (Hueston et al. 2014), terdapat 3 kesimpulan penting meliputi: 1) kepemilikan tanah secara De Facto yang dapat diartikan bahwa bagi petani, tanah tidak hanya bermakna material/ekonomi tapi juga berhubungan erat dengan masalah sosial-budaya, dimana tanah menjadi simbol terhadap status sosial ekonomi bagi petani dalam komunitasnya; 2) subordinasi legal yang diartikan sebagai kelas sosial petani berada di bawah kelas sosial tuan tanah; dan 3) kekhususan kutural. Dengan berbagai konsepsi yang dikemukakan dalam mendeskripsikan petani yang pada dasarnya secara diametral tidak berbeda satu sama lain. Hal ini terkait dengan maksud untuk saling menyempurnakan dan tergantung dari berbagai sisi dan cara pandang mereka masing-masing. Sedangkan kajian yang diperlukan adalah mengenai perubahan pola-pola hubungan, interaksi, institusi dan sebagainya yang dialami oleh masyarakat petani di sepanjang sejarah.

Adalah suatu keniscayaan bahwa peluang dan kesempatan bertani sebagai sumber nafkah rumah tangga petani menjadi berkurang bahkan menghilang sebagai konsekuensi yang diakibatkan dari berlakunya sistem pembangunan di era modernisasi seperti sekarang ini. Dampak secara nyata diterima oleh petani sebagai akibat dari pelaksanaan sistem pembangunan tesebut terhadap kehidupan petani di pedesaan hendaknya digunakan untuk mengkaji kemungkinan dan potensi pemberdayaan petani dengan tujuannya agar masyarakat petani dengan cirikhasnya bisa beradaptasi dan berkelanjutan tanpa harus kehilangan norma-norma dan nilai-nilai pengetahuan lokal yang menjiwainya.

\section{Pemberdayaan Potensi Sumber Pendapatan Petani}

Pemberdayaan petani menjadi petani mandiri dan profesional dapat dilakukan melalui beberapa langkah, dinataranya: 1) meningkatkan kualitas sumber daya manusia petani melalui pelatihan, penelitian, magang dan sebagainya, baik secara individu maupun kelompok; 2) melakukan 
revitalisasi kelompok tani mandiri ke arah kelembagaan formal berbadan hukum (koperasi petani atau koperasi agribisnis, asosiasi petani komoditas tertentu); 3) mengangkat penyuluh swakarsa atau petani petandu (dalam program SLPHT) sebagai mitra penyuluh untuk memperlancar difusi dan adopsi teknologi; dan 4) memberdayakan kelembagaan penyuluhan pertanian \& kelembagaan Balai Penyuluhan Pertanian (BPP) menjadi Pusat Pelayanan sekaligus Konsultasi Agribisnis (PPA) di setiap kecamatan melalui sistem penyuluhan partisipatif. Undang-undang Republik Indonesia Nomor 19 Tahun 2013 Tentang Perlindungan dan Pemberdayaan Petani Pasal 1 BAB I, dalam Undang-undang ini yang dimaksud dengan: "Pemberdayaan Petani adalah segala upaya untuk meningkatkan kemampuan Petani untuk melaksanakan Usaha Tani yang lebih baik melalui pendidikan dan pelatihan, penyuluhan dan pendampingan, pengembangan sistem dan sarana pemasaran hasil pertanian, konsolidasi dan jaminan luasan lahan pertanian, kemudahan akses ilmu pengetahuan, teknologi dan informasi, serta penguatan kelembagaaan Petani."

Pemberdayaan petani harus dilihat sebagai upaya untuk meningkatkan kemampuan internal petani sekaligus juga membuka akses dan kesempatan yang lebih bagi petani untuk mendapatkan dukungan sumber daya produktif maupun untuk mengembangkan usaha yang mampu menyejahterakan masyarakat (Ardika \& Budhiasa, 2017). Penyuluhan dan pendidikan pertanian menjadi agenda operasional yang sangat penting, karena pemberdayaan merupaka sebuah proses menjadi, bukan sebuah proses instant. Sebagai proses, pemberdayaan mempunyai tiga tahapan: 1) penyadaran; 2) pengkapasitasan; dan 3) pendayaan (Fahrudin, 2011).

Dalam penciptaan iklim yang dapat menunjang pemberdayaan petani melalui sumber mata pencahariannya maka diperlukan beberapa upaya konkrit (Sari, 2017): 1) melibatkan peran tokoh informal dalam kegiatan penggalangan SDM petani secara sosial dan ekonomi; 2) melibatkan tokoh agama dalam membangun etos kerja dan strategi hidup produktif dan hemat; 3) memberikan pelatihan/peningkatan kemampuan SDM agar dapat mengarahkan petani pada unit ekonomi yang produktif; 4) dan melakukan pengkaderan bagi generasi petani lewat keterampilan atau persepsi nilai kerja agar tidak terjadi putusnya generasi pekerja pertanian dalam masyarakat di pedesaan. Di samping itu secara evolutif, pengeluaran anggota rumah tangga petani berusaha lebih diefisienkan dan diarahkan dari hal-hal yang bersifat seremonial yang umumnya boros dengan mengarahkannya kepada aktivitas yang hemat waktu dan biaya (D. Sari, Haryono, \& Rosanti, 2014). Jadi, sifat kedinamisan pemberdayaan tersebut selalu diperhatikan sebagai faktor utama dalam penyesuaian sebagai langkah menuju pencapaian keseimbangan terhadap berbagai perubahan yang akan terjadi.

\section{Eksistensi Petani dalam Konsepsi Ekonomi Kerakyatan}

Berlakunya era globalisasi memiliki implikasi terhadap semakin terbukanya akses petani sebagai suatu proses perubahan akibat perkembangan teknologi dan daerah yang membutuhkan perlunya strategi alternatif dalam mengatasi berbagai masalah 
petani. Upaya yang harus dilakukan oleh mereka adalah menekan pola konsumsi yang konsumeris dengan menyesuaikan pengeluaran dan penghasilan dalam rangka mengerahkan seluruh anggota keluarga untuk dapat menghasilkan bahan makanan dan barang kebutuhan lainnya. Sekaligus keadaan ini memiliki makna untuk membuktikan bahwa kaum tani selalu dinamis (tidak statis seperti yang secara klise dalam kepustakaan), selalu bergerak terus antara dua kutub untuk mencari pemecahan dilema pokok mereka. Keadaan tersebut harus melibatkan proses pemberdayaan sebagai tahap untuk adaptasi untuk menopang mereka dalam mempertahankan diri dan sesamanya dalam suatu tatanan hidup sosial.

Sistem yang bersifat Top Down atau sentralitas dan mekanisme pembangunan yang terwujud dalam aplikasi teknologi berisi input eksternal yang menuntut modal tinggi untuk memperbaiki proses produksi dan memperbaiki produktivitas dalam konteks pemanfatannya hanya mampu diadopsi dan dinikmati petani berlahan luas atau petani modern dengan capital besar dan berorentasi pasar. Dalam prakteknya, penerapan teknologi tersebut berdampak luas terutama menjadi longgarnya ikatan nilai dan norma lokal yang berorientasi sosial dan bersifat komunal sebagai akibat yang lebih mengedepankan efisiensi ekonomi. Sementara untuk pengetahuan lokal yang ada dan berkembang di masyarakat justru dalam penerapan dan pelestariannya semakin terhambat.

Implikasi dari keadaan tersebut, menjadikan masyarakat semakin tergantung pada nilai dan kekuatan luar desa seperti pasar dan industri perkotaan yang bersifat ekonomi dan individualis, dimana ukuran yang digunakan tidak lagi menyangkut kelestarian dan kebersamaan melainkan eksploitasi dan sukses finansial semata. Jika kondisi ini sudah berlangsung maka dampaknya adalah kehidupan masyarakat desa bisa diartikan sangat rapuh terhadap faktor yang berada diluar pengendaliannya. Menurut (Chiari, 2015) Implikasi berikutnya, memudarnya keterjaminan sumber nafkah bagi kaum tani yang selama ini eksis dan hidup di pedesaan akibat memudarnya sistem ekonomi moral yang sebenarnya; dimana etika subsistensi yang berakar dalam kebiasaan ekonomi dan pertukaran sosial tidak dapat difungsikan dalam era pembangunan modern.

Ekonomi Kerakyatan bukanlah suatu gagasan atau ideologi baru tentang perekonomian, namun merupakan percobaan perumusan dasar interpretasi serta cita-cita pembangunan masyarakat adil dan makmur. Untuk itu, dalam penyusunan suatu konsep pembangunan perlu dipahami, sedikitnya tiga pertanyaan pokok yang sangat penting untuk mengetahui kejelasan hubungan antara konsep pembangunan dan ideologi yang mendasarinya, yaitu: hal orientasi dan arah pembangunan; apakah dan siapakah yang menjadi pendorong dan pelaksana pembangunan tersebut; dan dalam suasana sosial politik yang bagaimana pembangunan tersebut diadakan.

Konsep ekonomi kerakyatan dan efisiensi yang menjadi pertimbangan sebagai dasar penyesuaian dalam upaya pemberdayaan petani demi peningkatan pendapatan yang berimplikasi terhadap peningkatan kesejahteraan rumah tangga 
pedesaan (Elizabeth, 2016). Berikutnya berdampak terhadap paradigma pembangunan pertanian yang harus direvitalisasi menjadi peningkatan kualitas hidup dan kesejahteraan petani serta pembangunan pedesaan. Oleh sebab itu diperlukan upaya untuk merevitalisasi kebijakan pembangunan pertanian baru melalui: 1) partisipasi aktif sebagai pemberdayaan petani dan masyarakat pedesaan; 2) pengembangan SDM; 3) peningkatan penguasaan lahan dan asset produktif. Selain itu, diperlukan juga upaya pemerataan pemilikan pada aset produktif pertanian, teknologi, dan pembiayaan. Dengan strategi ini diharapkan sektor pertanian akan menjadi basis pertumbuhan ekonomi Indonesia dimasa yang akan datang.

\section{Kesimpulan}

Dengan kekayaan alam yang berlimpah baik berupa rempah-rempah maupun hasil pangan dan peran penting petani dalam kehidupan masyarakat Indonesia. Pentingnya peran petani bagi bangsa Indonesia belum mampu menjelaskan kesejahteran hidup petani karena keadaan petani masih dihadapkan dengan berbagai permasalahan, diantaranya: masalah kemiskinan, ketimpangan struktur penguasaan lahan, dan terjadi penyusutan lahan pertanian produktif.

Tekanan ekonomi kapitalis ke pedesaan melalui penerapan teknologi modern dan sistem pasar yang mengutamakan efisiensi tidak hanya berdampak pada hilangnya kesempatan berusahatani bagi petani. Namun, justru berdampak pada semakin longgar dan melemahnya ikatan sosial yang terjalin dalam kehidupan masyarakat di pedesaan sehingga diperlukan revitalisasi melalui pemberdayaan untuk meningkatkan peran petani sebagai asset pembangunan.

Keterbatasan petani merupakan salah satu sebab yang mendasari terjadinya kemiskinan. Sedangkan untuk mengatasi keterbatasan petani dan memungkinkan mengembangkan kerangka institusional yang dapat mengaitkan teknologi tepat guna dengan petani secara sistem interaktif secara mandiri. Lebih jauh lagi kemiskian dilukiskan sebagai kondisi struktural sehingga diperlukan perubahan struktural untuk mengatasinya. Beranjak dari kondisi tersebut, perlu adanya perubahan persepsi terhadap pekerjaan sektor pertanian yang selam ini dipandang sebagai pekerjaan kurang terhormat dan alternatif terakhir.

\section{Saran}

Pentingnya upaya revitalisasi paradigma dan kebijakan pembangunan pertanian baru melalui pendekatan sumber daya alam dan teknologi ke arah pembangunan pertanian yang lebih Holistic (SDA, SDM, teknologi dan kelembagaan) dengan partisipasi aktif melalui: 1) pemberdayaan petani dan masyarakat pedesaan; 2) pengembangan sumber daya manusia; 3) peningkatan penguasaan lahan dan asset produktif; 4) pemerataan dan peningkatan kepemilikan asset produktif pertanian; 5) teknologi; 6) pembiayaan; 7) pengembangan pertanian pedesaan; 8) penguatan lembaga keuangan pedesaan yang mandiri; dan 9) pengembangan basis sumberdaya pertanian. 


\section{Daftar Pustaka}

Ardika, I Wayan, dan Gede Sujana Budhiasa. 2017. "Analisis Tingkat Kesejahteraan Petani di Desa Bangli Kecamatan Baturiti Kabupaten Tabanan.” Jurnal Piramida XIII(2): 87-96.

Ariani, Hana, Efri Syamsul Bahri, dan Zainal Arif. 2016. "Analisis Pemberdayaan Petani Dhuafa (Studi Kasus Di Pertanian Sehat Indonesia)." jurnal komunikasi antar perguruan tinggi agama islam: 275-94.

Budhijana, R Bambang. 2014. "Perspektif Ekonomi Islam Dalam Sustainable Development Pada Produktivitas Petani Pedesaan." Jurnal Ekonomi 15(3).

Chiari, Anwar. 2015. "Strategi Bertahan Hidup Petani Saat Musim Kemarau (Studi pada Petani Sayur Desa Tulungrejo, Kecamatan Bumiaji, Kota Batu)." jurnal mahasisw sosiologi.

Elizabeth, Roosganda. 2016. "Fenomena Sosiologis Metamorphosis Petani: ke Arah Keberpihakan pada Masyarakat Petani di Pedesaan yang Terpinggirkan Terkait Konsep Ekonomi Kerakyatan." Forum penelitian Agro Ekonomi 25(1): 29.

Fahrudin, Adi. 2011. "Pemberdayaan, Partisipasi Dan Penguatan Kapasitas Masyarakat." humaniora: $1-5$.

Ferianti, I $\quad$ R $\quad$ A. 2018. "Pemberdayaanmasyarakat Petani Dalam Meningkatkan Hasil Panen Padi Melalui Program Kelompok Tani."

Hueston, W. D., L. E. Heider, W. R. Harvey, dan K. L. Smith. 2014. "Determinants of high somatic cell count prevalence in dairy herds practicing teat dipping and dry cow therapy and with no evidence of Streptococcus agalactiae on repeated bulk tank milk examination." Preventive Veterinary Medicine 9(2): 131-42.

Ilham, N, dan Endang Lestari Hastuti, Kedi Suradisastra Tri Pranadji, Adang Agustian, Gatoet Sroe Hardono. 2007. "Analisis profil Petani dan Pertanian Indonesia." Rinpse.litbang.pertanian.go.id > pdffiles > LHP_NYK_2007. http://pse.litbang.pertanian.go.id/in d/pdffiles/LHP_NYK_2007.pdf.

Ismail, Gofar, Supardi Suprapti, dan Wahyuningsih Sri. 2008. "Analysis Efficiency Marketing System Of Fresh Layang Fish (Decapterus Russeli) On Pelabuhan Fish Auction Place In Tegal City." Mediagro 4(2): 39-50.

Kurniawan, Hendra. 2014. "Dampak Sistem Tanam Paksa terhadap Dinamika Perekonomian Petani Jawa 18301870." SOCIA: Jurnal Ilmu-Ilmu Sosial 11(2): 163-72.

Meiyani, Eliza. 2010. "Sistem Kekerabatan Orang Bugis Di Sulawesi Selatan." Al Qalam 16.

Meiyenti, Sri, dan . Syahrizal. 2014. "Perubahan Istilah Kekerabatan Dan Hubungannya Dengan Sistem Kekerabatan Pada Masyarakat Minangkabau." Jurnal Antropologi: Isu-Isu Sosial Budaya 16(1): 57.

Melati, Febrian Fatma. 2013. "Dinamika Perubahan Sosial dan Budaya di Desa Kendalsari, Kecamatan Sumobito, Kabupaten Jombang." AntroUnairDotNet 2(1): 291-97.

Miftah, Himmatul, dan Ahmad Syarbaini. 2014. "Model Pemberdayaan Petani Ubikayu Melalui Pola Klaster Sistem Agribisnis Terintegrasi Di Kabupaten Sukabumi Provinsi Jawa Barat." SEPA: Jurnal Sosial Ekonomi Pertanian dan Agribisnis 10(2): 298. 
Mirzaqon, Abdi, dan Budi Purwoko. 2018. "Studi Kepustakaan Mengenai Landasan Teori Dan Praktik Konseling Expressive Writing Library." Jurnal BK UNESA (1): 18.

Normansyah, Dodi, Siti Rochaeni, dan Armaeni Dwi Humaerah. 2014. "Analisis Pendapatan Usahatani Sayuran Di Kelompok Tani Jaya, Desa Ciaruteun Ilir, Kecamatan Cibungbulang, Kabupaten Bogor." Agribusiness Journal 8(1): 29-44.

Nuraini, Nina. 2018. "Analisis kualitas hidup petani pangan di desa dringu kecamatan dringu kabupaten probolinggo." Journal of Chemical Information and Modeling 53(9): 1689-99.

Pendapatan, Analisis, Usahatani Dusung, Di Desa, dan Hutumuri Kota. 2017. "Median Volume IX Nomor 1 Bulan Februari 2017 Analisis Pendapatan Usahatani Dusung Di Desa Hutumuri Kota Ambon.” IX.

Rohmiati amini, baiq salkiah. 2018. "Strategi Peningkatan Kesejahteraan Masyarakat Nelayan."

Sadono, Dwi. 2008. "Pemberdayaan Petani: Paradigma Baru Penyuluhan Pertanian di Indonesia." Jurnal Penyuluhan 4(1).

Sari, Dian, Dwi Haryono, dan Novi Rosanti. 2014. "Analisis Pendapatan Dan Tingkat Kesejahteraan Rumah Tangga Petani Jagung Di Kecamatan Natar Kabupaten Lampung Selatan." Jurnal IlmuIlmu Agribisnis 2(1): 7.

Sari, Novita. 2017. "Analisis SumberSumber Pendapatan Petani Di Desa Kepenghuluan Mumugo Kecamatan Tanah Putih Kabupaten Rokan Hilir Oleh." Journal Of Chemical Information And Modeling 53(9): 1689-99.
Sidiq, Baehaqi. 2014. "Kata kunci : Dampak industri,Kerja Sama, Perubahan Sosial." 2(4): 39-50.

Sinaga, Astriana Baiti, dan Sumardjo. 2007. "Pemberdayaan Petani Sayuran: Kasus Petani Sayuran Di Sulawesi Selatan." Jurnal Penyuluhan 3(1): p.18-23. http://download.portalgaruda.org/ar ticle.php? article $=83419 \& \mathrm{val}=222$ \& title=Empowerment of Vegetable's Farmers:Case Study of Vegetable's Farmers in South Sulawesi.

Suharto, Edi. 2014. Membangun masyarakat, memberdayakan rakyat: kajian strategis pembangunan kesejahteraan sosial dan pekerjaan sosial.

Suradisastra, Kedi. 2008. "Strategi Pemberdayaan Kelembagaan Petani." Forum penelitian Agro Ekonomi 26(2): 82.

Suyanto, Bagong. 2001. "Kemiskinan dan Pemberdayaan Masyarakat Miskin." Masyarakat, Kebudayaan dan Politik 14(4): 25-42.

Tanziha, Ikeu. 2011. "Model Pemberdayaan Petani Menuju Ketahanan Pangan Keluarga.” Jurnal Gizi dan Pangan 6(1): 90.

Wiradi, Gunawan. 2004. "menelusuri pengertian istilah agraria." analisis sosial 9(1). 